\title{
INFLUENCE OF SUBJECTIVISM ON THE EFFECTIVENESS OF STATE FINANCIAL CONTROL IN THE AREA OF BUDGET ALLOCATION
}

\author{
Tetiana Mishchenko' \\ University of State Fiscal Service of Ukraine, Ukraine
}

\begin{abstract}
The purpose of the article is to study the impact of subjects of state financial control, primarily internal, over the budget on all levels of executive power, in order to eliminate subjectivity in their actions and increase the efficiency of public finances in general. Method. The study, which requires a deeper consideration of the issue of transformation of the content of the role performed by subjects of state financial control, primarily internal, in the presence of crisis phenomena in the economy. Methodology. The study of this issue is based on the analysis of the performance of the State Audit Service of Ukraine in identifying violations that led to losses of financial and material resources for the period of 2011-2017. Results. In our opinion, the dynamics of a constant decrease in the size of eliminated financial violations testifies to the insignificant effectiveness of the implemented control measures. The lowest, according to statistical indicators, is an indicator of elimination of financial violations in recent years, as well, the number of financial audits has also decreased significantly. Moreover, the number of inspections in individual cases had no effect on the final result. At the same time, the transition to new standards of inspections, with a view to deregulating and reducing the level of subjectivism, is less effective, but more transparent, which is positive in a slowdown of the economy, despite a certain reduction, but there is a significant level of corruption. Subjectivity in the actions of the controlling bodies can exert significant pressure on the entities subject to their supervision. Therefore, in order to achieve an optimal balance between the effectiveness of control measures and the reduction of pressure on economic entities, it is necessary to bring the existing system to standards that correspond to the level of developed countries. Currently, the process of changing approaches to inspections is based on the selection of objects that are subject to inspections based on a prior assessment of risks. Practical implications. The domestic system of internal state financial control is characterized by a significant level of subjectivism. It is substantiated that the reorganization of the system of internal state financial control is directly related to the reorganization of the entire system of public finances, in particular, one of its most important components - the system of state purchases.
\end{abstract}

Key words: state financial control, public finances, budget, elimination of financial violations, State Audit Service of Ukraine.

JEL Classification: $\mathrm{H} 61, \mathrm{H} 72, \mathrm{H} 83$

\section{Introduction}

State financial control is the main factor, on which the entire system of public finances is based. The effectiveness of the implementation of state financial control is directly related to the entities that implement it. During all years of independence, the quality of public financial control causes considerable debate and controversy, because subjectivism in this area can lead to both positive and negative impacts on the budget sphere in general.

The urgency of this problem is also determined by the fact that the reduction of the influence of subjectivity on state financial control positively affects the reform of the entire state sector of the economy, which was launched and implemented in recent years. All this will contribute to the unification and coherence of public finance control at all levels.

The implementation of the state financial control should aim at: achieving the main strategic national development goals; optimizing the use of budget funds by state authorities, including controllers; effective allocation of budgetary resources necessary for the exercise of state functions; ensuring the reduction of financial security imbalances between different territories and social groups; minimizing risks that may arise in the field of public administration. 
The issues of fairness and transparency of redistribution of budget resources are particularly acute during times of aggravation of the crisis phenomena that are peculiar for Ukraine in recent years. In addition, the latest economic and profound socio-political crisis calls for increased control over the sphere of state expenditures, which is directly the competence of state financial control. Therefore, subjectivity in the field of state financial control in terms of deceleration of economic growth and revenues to the state budget should be kept to a minimum. Taking into account the above, one can state that the problem under investigation is extremely relevant for Ukraine and needs more detailed consideration.

The issue of the role and importance of subjects of state financial control in terms of ensuring the redistribution of budget funds is relevant not only for Ukraine but also for other countries. So, scholars of other countries, who consider the role and functions of subjects of state regulation, include: A.M. Babich, V.V. Burtsev, L.I. Voronina, Ye.Yu. Hrachova, A.V. Krykunov. A considerable attention is paid to the research of this issue by domestic scientists, including: N.S. Vitvytska, N.H. Vyhovska, H.V. Dmytrenko, I.K. Drozd, V.P. Dudko, Ye.V. Kaliuha, and other scholars.

Despite a large number of scientific papers on the role and place of the subjects of state control in the context of the provision of redistribution of budget funds, some aspects of this issue are still insufficiently researched. Thus, a deeper consideration is required for issues of transformation of the content of the role performed by subjects of state financial control, primarily internal, in the presence of crisis phenomena in the economy. Also, insufficient attention is paid to mechanisms of minimization of the influence of subjectivity in the field of control over budgetary funds, including, in order to strengthen financial discipline on the part of executive authorities of all levels.

\section{Subjects of internal state financial control}

In the vast majority of developed countries, including Ukraine, state financial control is based on the principles approved by the Lima Congress. Ukraine, along with other countries, is a full member of the Congress and signed the Declaration, which provides for transparency in the use and disposal of budget funds (Stefaniuk, 2011). The main Lima principles include: preliminary and factual control, independent external and internal control, financial independence, investigative character, accountability, control over the receipt of taxes, public procurement openness principle. These principles, if fully implemented, can ensure the transparency of state financial control.

In Ukraine, in accordance with Article 95 of the Constitution, it is envisaged that the budget system should be based on the principles of fairness and impartiality of redistribution of public financial resources among all citizens, as well as local communities (Constitution of Ukraine, 1996). At the same time, the position declared in the Constitution is not always implemented in practice, which is primarily related to a significant number of subjective factors.

State financial control is carried out on behalf of the state by authorized entities and is divided into internal and external. Internal state financial control is implemented at the level of executive power, while the external - by independent and authorized bodies within the Constitution (Polishchuk, 2014).

Internal state financial control plays a special role in the context of the study of subjectivism in controlling the distribution of budgetary funds, since it is on the actors that carry it out, for the most part, the transparency and efficiency of the redistribution of public finances depend, as well as whether violations will be systemic or vice versa will be effectively eliminated in the future.

Internal financial control is still divided into government and departmental, and the main subjects that carry it out are: State Audit Service of Ukraine, Ministry of Finance of Ukraine, State Financial Monitoring Service of Ukraine, State Fiscal Service of Ukraine, State Treasury Service of Ukraine.

The main subject of internal state financial control is the State Audit Service of Ukraine. This body of state power has undergone a long-term evolution of its own development and replaced two previous ones: The Main Control and Audit Office of Ukraine, which existed until 2011, and later - the State Financial Intelligence of Ukraine, which lasted until 2015. These subjects of the state financial control over a long period of time were given sufficiently wide powers and practically carried out inspections autonomously from the Ministry of Finance of Ukraine.

The problem of functioning of the predecessors of the State Audit Service of Ukraine was primarily in the field of their activities in relation to controlled entities, which in particular were and still exist: all executive authorities; departments and ministries; state trust funds; budgetary institutions; other economic entities connected with budget funds through the system of state purchases.

The greatest subjectivism in the actions of the predecessors of the current State Audit Service was connected with the verification of business entities that had a connection with the receipt of funds from any budget because of the system of public procurement existing for a certain period of time. The very issues related to the conduct of inspections of economic entities that were related to the field of procurement were the most controversial. The number of such inspections was not only high, but it also had a significant negative impact on business entities, as it could lead to a lengthy procedure. In addition, the lack of a single set of rules for selecting entities subject to inspections deepened the 
subjectivity in the implementation of control and audit activities. Another factor contributing to this was the fact that such actions could also be initiated by direct orders and appeals of the President of Ukraine, the Presidential Secretariat, the Cabinet of Ministers, the Verkhovna Rada, and people's deputies of Ukraine. Starting from 2014, this factor of influence was eliminated, and indicators on the availability of audits initiated by these entities are not reflected in the statistics of activities of the State Audit Service.

The reformation started in 2011, despite the fact that it was aimed at certain changes in approaches existing during all previous years, was of a limited nature over the practical absence of changes in other areas related to the implementation of state financial control.

Starting in 2014, the reform of the state branch of government and structural elements that belonged to it began. In the context of the implementation of reforms and the approximation of internal financial control to a level that would meet European standards, the State Financial Inspection of Ukraine was transformed into the State Audit Service of Ukraine (in accordance with the Decree of the Cabinet of Ministers of Ukraine "On Establishment of the State Audit Service” № 868 on 28 October 2015). One of the main reasons for such changes was the need to put into practice requirements of the European Union regarding the optimization of the number and improvement of the quality of controlling bodies in order to ensure a more effective fight against corruption. In this context, a significant reduction (up to 50\%) in the number of employees of the State Audit Service was envisaged.

\section{Analysis of results of control measures}

In order to identify the effectiveness of the functioning of the State Audit Service, in comparison with the State Financial Inspection of Ukraine, it is necessary to compare indicators of their activity in recent years, starting with the existence of the latter in 2011. Let us consider in more detail the results of the revealed financial violations, which led to losses of financial and material resources in the period from 2011 to 2017 (State Financial Inspection of Ukraine, 2011-2013; State Audit Service of Ukraine, 2016-2017).

According to data shown in Fig. 1, it can be concluded that the largest amounts of financial violations were detected in 2014 when tendencies towards a gradual reform of the system of elements of the government branch began. At the same time, in recent years since 2014, there were trends in reducing the number of identified financial violations. Moreover, this reduction was applied to almost all directions, and in some of them, in particular, such as shortfall of financial resources and illegal expenses, in 2017, compared with 2014, decreased by 4.9 times (from 3159447.97 thousand UAH in 2014 to 642868.39 thousand UAH in 2017) and 3.4 times (from 3888086.69 thousand UAH in 2014 to 1122603.30 thousand UAH in 2017) (State Audit Service of Ukraine, 2016-2017). At the same time, an attention should be paid to tendencies of recent years in relation to changes in the number of control measures carried out (Fig. 2).

As it can be seen from Fig. 2, similar to the results of detected financial violations, the largest number was observed in 2014, after which it began to decrease

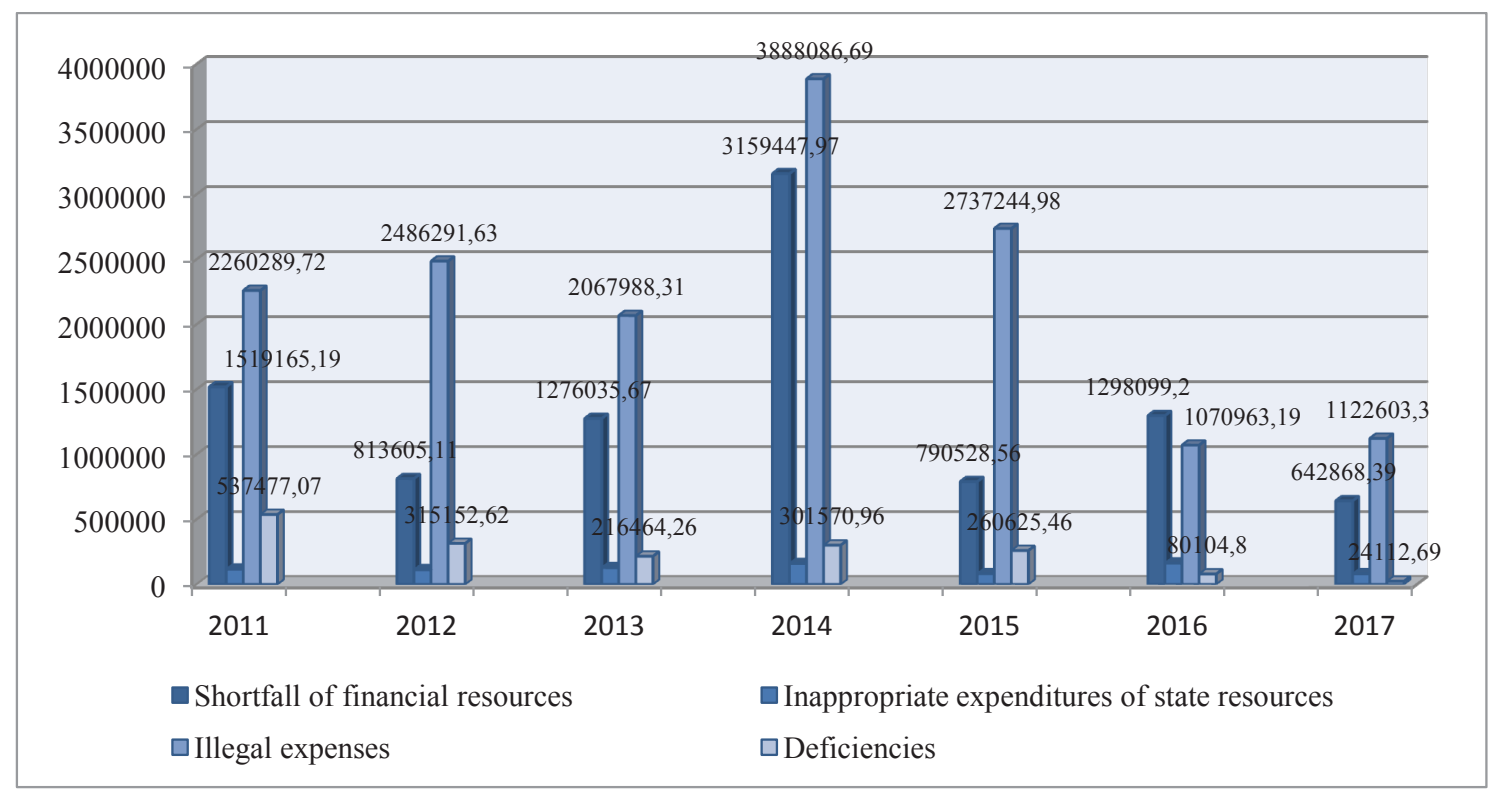

Fig. 1. Results of revealed financial violations, which led to losses of financial and material resources for the period of 2011-2017 (in thousand UAH) 


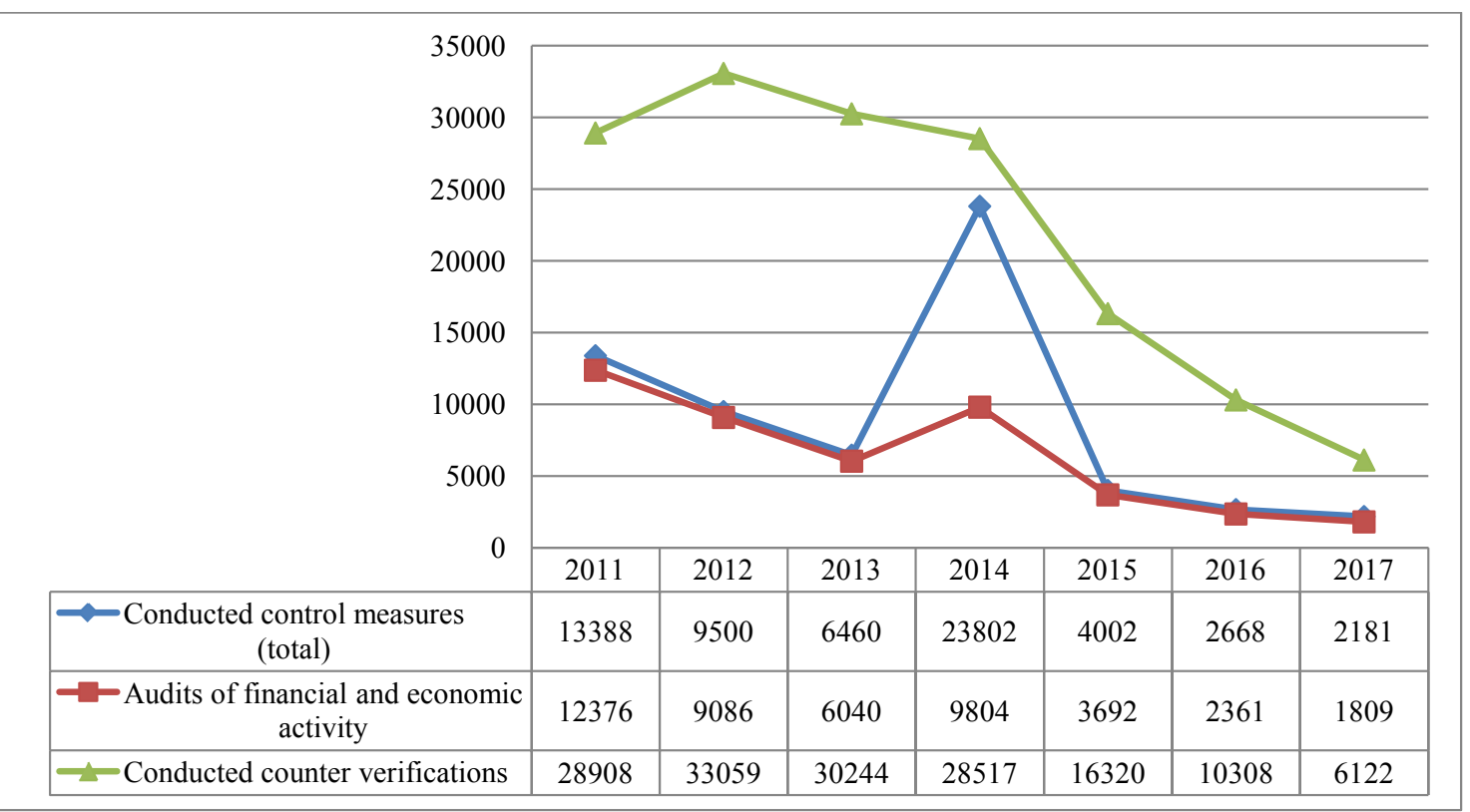

Fig. 2. Indicators of changes in the number of control measures in 2011-2017 (number)

rapidly. In comparison with 2014, in 2017 the number of control measures decreased by almost 10 times (from 23802 in 2014 to 2181 in 2017) (State Audit Service of Ukraine, 2016-2017). Reducing the number of control measures is associated with changing approaches to their implementation. Thus, starting in 2012, a planned approach to control and audit activity, which involves risk assessment, using various kinds of information regarding the existence of violations of financial discipline, monitoring, civil society appeals, etc., began to be implemented. It is on this basis that the selection of objects that fall under control measures should be carried out (Luchko, 2015).

The orientation of the State Audit Service is not on the quantity but on the scope of economic activities that bear the greatest risks and the analysis of the largest financial flows, as the object of control should provide significant control effectiveness in practice. Let us consider the most important quantitative indicators that directly relate to the elimination of identified financial violations in Table 1.

Based on the data presented in Table 1, an attention is paid to the continuous and rapid reduction of the effectiveness of elimination of financial violations for the investigated period of existence of the State Financial Inspection of Ukraine and from 2015 the State Audit Service. Such indicators were the lowest in 2016. Thus, compared to 2011, the amount of eliminated financial violations decreased by 13.4 times (from 8190738.9 thousand UAH in 2011 to 611508.9 thousand UAH in 2016) (State Financial Inspection of Ukraine, 2011-2013; State Audit Service of Ukraine, 2016-2017).

Table 1

Financial indicators that characterize the state of elimination of identified violations during 2011-2017 (in thousand UAH)

\begin{tabular}{|c|c|c|c|c|c|c|c|}
\hline Indicators & 2011 & 2012 & 2013 & 2014 & 2015 & 2016 & 2017 \\
\hline $\begin{array}{c}\text { Eliminated financial violations that } \\
\text { resulted in the loss of financial and } \\
\text { material resources (total) }\end{array}$ & 8190738,9 & 1927480,5 & 1474001,7 & 990262,8 & 752977,7 & 611508,9 & 787975,48 \\
\hline $\begin{array}{c}\text { Received financial resources (total) to } \\
\text { budgets and trust funds }\end{array}$ & 653664,8 & 731538,6 & 389903,8 & 252942,5 & 203841,8 & 141281,3 & 225219,63 \\
\hline $\begin{array}{c}\text { Reimbursed and renewed expenses of } \\
\text { financial and material resources (total), } \\
\text { including: }\end{array}$ & 7537074,1 & 1195941,9 & 1084097,8 & 737320,3 & 549135,9 & 470227,6 & 562755,85 \\
\hline $\begin{array}{c}\text { - Inappropriate expenditures of state } \\
\text { resources }\end{array}$ & 2569379 & 91711,8 & 97099,1 & 96448 & 51054 & 54529,6 & 119802,96 \\
\hline - Illegal expenses & 4927180,85 & 1075361,4 & 854049,54 & 620644,3 & 478498 & 407410,8 & 434263,00 \\
\hline - Deficiencies & 40514,2 & 28458,8 & 132949,2 & 20227,9 & 19583,7 & 8287,1 & 8689,89 \\
\hline
\end{tabular}

Source: compiled on the basis of (State Financial Inspection of Ukraine, 2011-2013; State Audit Service of Ukraine, 2016-2017) 
Also, the size of reimbursements and renewal of financial resources, which make up the predominant part of the overall structure of elimination of financial violations, has significantly decreased. During 2011-2017, this indicator decreased by 13 times (from 7537074,1 thousand UAH in 2011 to 562755,85 thousand UAH in 2017) (State Financial Inspection of Ukraine, 2011-2013; State Audit Service of Ukraine of Ukraine, 2016-2017).

\section{New approaches to internal financial control}

The change in approaches to internal financial control was aimed at two main objectives: 1 . to reduce fiscal pressure on business entities and, thus, to introduce deregulation processes in this field; 2 . reducing the number of inspections and using an approach that involves determining risk, improve their quality (Pikhotskyi, 2015).

Analysing statistical data for recent years, in our opinion, the dynamics of a constant decrease in the size of eliminated financial violations testifies to the insignificant effectiveness of the implemented control measures. Moreover, the number of inspections in individual cases had no effect on the final result. Thus, in particular, the largest number of control measures for the research period of 2011-2017 was in 2014 and amounted to 23802, while the financial result in the form of elimination of financial violations was only 1.2 times higher than in 2017, when the number of inspections carried out was lower than 11 times (State Audit Service of Ukraine, 2016-2017).

It should also be noted that throughout the years since the establishment in 1993 of the first body that implemented the internal state financial control (State Control and Audit Service of Ukraine) and to this day, even in a slightly reformed structure of the State Audit Service, there is a significant subjectivity in the implementation of control measures. This is determined by the very specific nature of changes and the selective nature of these processes.

In view of the results of the research, general results of recent years are also controversial. At the same time, it is also evident that although the existing to 2011 approach to the implementation of control measures had a strict administrative character, but was more effective, according to statistical data. So for a comparison, by the time of the first restructuring in 2010, the amount of eliminated financial violations was 2.4 times higher than in 2011 (when the State Financial Inspection of Ukraine was created) and 25.8 times more than in 2015. (when the State Audit Service of Ukraine operating today was created) (State Financial Inspection of Ukraine, 20112013; State Audit Service of Ukraine, 2016-2017).

Thus, we can conclude that the effectiveness of state control is rapidly reducing, which may be quite dangerous in terms of a slowdown of the economy, despite some reduction, but still a significant level of corruption.
However, quantitative results are not such as to exclusively characterize the current state of state financial control, as well as changes that take place in this area. This is associated with the fact that the reform of state financial control is not a separate process, but only one of the components of gradual introduction of the latest changes in the area of efficient allocation of budget funds. Positive changes, in particular, in launching the electronic public procurement system, in case of further comprehensive implementation and expansion, will have a direct impact on changing the approaches to conducting financial audits of business entities that participate in this system. Such changes, among other things, will contribute to the gradual reduction of the subjective influence on the audit process. At the same time, these changes can be realized with the implementation of further measures to reform all branches of state power and their key elements.

\section{Conclusions}

The study of the role and significance of subjects of internal state control over the system of public finances has made it possible to draw the following conclusions: - state financial control plays an important role in increasing the efficiency of distribution and redistribution of budget funds, while internal state financial control is the basis, on which the whole system of state finance management is built;

- the domestic system of internal financial control has the essential level of subjectivity, which for a long period of time was conditioned by the approach to audits, the content of which was reflected in the coverage of as many economic entities as possible;

- according to statistical indicators, before the first reformation in 2011, internal state financial control was the most effective, which, in particular, is testified by the elimination of financial violations, along with this, although the transition to new standards of inspections in order to deregulate and reduce the level of subjectivity is less effective but more transparent;

- the lowest, according to the statistical indicators, is an indicator of elimination of financial violations in recent years, as well, the number of financial audits itself has also significantly decreased. At the same time, such changes may also be related to another stage of the reform of the subject of internal state control in 2015, which resulted in the creation of the State Audit Service of Ukraine, which number of employees, as compared with previous years, was significantly reduced.

The prospect of a further study of the topic is to determine milestones of the completion of the transition of the existing system of state financial control in Ukraine to European standards of transparency and quality of implementation of functions entrusted to it. It is also promising to study the influence of external factors on changes in the system of state financial control, which, on the other hand, determines the further vector of such changes. 


\section{References:}

Stefaniuk, I. (2011). Derzhavnyi finansovyi kontrol: klasyfikatsiini kharakterystyky [State financial control : classification characteristics]. Herald of Kyiv national university of trade and economy, no. 4, pp. 42-51. (in Ukrainian)

Konstytutsiia Ukrainy (1996). [Constitution of Ukraine, as for 20 January, 2018. Codified text]. Retrieved from: http://zakon3.rada.gov.ua/laws/show/254\%D0\%BA/96-\%D0\%B2\%D1\%80/page2 (accessed 20 January 2018) (in Ukrainian)

Polishchuk, V. V. (2014). Napryamky udoskonalennya systemy derzhavnoho finansovoho kontrolyu: vprovadzhennya stratehichnoho audytu [Ways of state financial control system improvement: strategic audit implementation]. Public management: theory and practice, no. 1, pp. 145-149 (in Ukrainian)

Pro utvorennia Dergavnoi auditorskoi slugbu. Postanova Kabinetu Ministrov Ukrainy vid 28.10.2015 №868 [Concerning State auditing service establishing. Cabinet of Ministers of Ukraine Directive of October 28, 2015 №868]. Retrieved from: http://zakon2.rada.gov.ua/laws/show/868-2015-\%D0\%BF. (accessed 20 January 2018) (in Ukrainian)

Zvit pro resultaty diyalnosti Dergfininspectsii ta ii territorialnyh organiv za 2011 rik (stanom na 31.12.2011) [State financial inspection and its regional divisions performance, 2011 Final Report as of December 31, 2011]. Retrieved from: http://www.dkrs.gov.ua/kru/uk/publish/article/83794. (in Ukrainian)

Zvit pro resultaty diyalnosti Dergfininspectsii ta ii territorialnyh organiv za 2012 rik (stanom na 31.12.2012) [State financial inspection and its regional divisions performance, 2012 Final Report as of December 31, 2012]. Retrieved from: http://www.dkrs.gov.ua/kru/uk/publish/article/96310. (in Ukrainian)

Zvit pro resultaty diyalnosti Dergfininspectsii ta ii territorialnyh organiv za 2013 rik (stanom na 31.12.2013) [State financial inspection and its regional divisions performance, 2013 Final Report as of December 31, 2013]. Retrieved from: http://www.dkrs.gov.ua/kru/uk/publish/article/96310. (in Ukrainian)

Zvit pro resultaty diyalnosti Dergfininspectsii ta ii territorialnyh organiv za sichen-gruden 2016 roky (stanom na 31.12.2016) [State financial inspection and its regional divisions performance, 2016 Final Report as of December 31, 2016]. Retrieved from: http://dkrs.kmu.gov.ua/kru/doccatalog/document?id=132218. (in Ukrainian)

Zvit pro resultaty diyalnosti Dergfininspectsii ta ii territorialnyh organiv za sichen-gruden 2017 roky (stanom na 31.12.2017) [State financial inspection and its regional divisions performance, 2017 Final Report as of December 31, 2017]. Retrieved from: http://dkrs.kmu.gov.ua/kru/doccatalog/document?id=132218. (in Ukrainian)

Luchko, M. R. and others. (2015). Control u dergavnomy sectori economiki: navch. posib. [Control in the public sector of economy: manual]. Ternopil: TNEU. (in Ukrainian)

Pikhotskyi, V. F. (2015). Systema dergavnogo financovogo controliu v Ukraini: contseptyalni zasadu teorii i practiki. Avtoreferat dissertatsii doctora economichnih nauk. [State financial control system in Ukraine: conceptual basics in theory and practice. Extended abstract of $\mathrm{PhD}$ dissertation in economics]. Lviv: National University named after I. Franko. (in Ukrainian) 